\title{
Pandangan Aksiologi Terhadap Riset Dan Aplikasi Senjata Biologis
}

\author{
Euis Erlin \\ Program Studi Pendidikan Biologi,FKIP Universitas Galuh Ciamis \\ e-mail: erlin123@gmail.com
}

\begin{abstract}
Kemajuan bioteknologi selayaknya menyumbangkan manfaat untuk kesejahteraan manusia serta harus mempertimbangkan nilai-nilai moral dan kemanusiaan. Hal ini bertentangan dengan penggunaan senjata biologis sebagai senjata yang mampu menjadi pemusnah masal.Dalam kajian filsafat, penggunaan senjata biologis ini dapat dipandang menurut pandangan aksiologi yaitu teori yang berkaitan dengan kegunaan dari pengetahuan yang diperoleh dan menujukkan kaidah-kaidah yang harus kita perhatikan dalam menerapkan ilmu menjadi hal yang praktis. Aksiologi memuat pemikiran tentang masalah nilai-nilai termasuk nilai-nilai moral, agama, dan nilai keindahan. Aksiologi mampu memberikan jawaban atas beberapa pertanyaan yang berkaitan dengan kegunaan ilmu pengetahuan, hubungan antara kegunaan dan kaidah moral, penentuan objek sesuai kaidah moral, dan hubungan antara teknik dan prosedur metoda ilmiah dengan norma-norma moral. Dalam hal ini penerapan teknologi rekayasa genetika dalam pembuatan senjata biologis pemusnah masal harus mempertimbangkan nilai-nilai moral dan kemanusiaan.
\end{abstract}

Keywords: Aksiologi, Senjata Biologis

\section{Pendahuluan}

Berkembangnya ilmu pengetahuan akan seirama dengan tumbuh kembangnya peradaban umat manusia. Melihat dari sebuah perjalanan sejarah, ilmu pengetahuan (sains) mengalami perkembangan yang sangat drastis dari masa ke masa. Dari awal tunbuhnya sains sampai berkembangnya sains, para ilmuwan tak pernah behenti berusaha ingin menemukan sesuatu yang baru dan selalu mencoba bagaimana ia mendapatkan sebuah sains yang belum pemah ada di zaman dahulu dan sekarang. Seiring dengan perkembangan ilmu tersebut, maka peran ontologi, epistimologi ,dan aksiologi senantiasa mewamai ilmu tersebut

Peradaban manusia sejak kemunculannya tidak dapat dilepaskan dari perkembangan ilmu pengetahuan dan teknologi. Berkat perkembangan ilmu pengetahuan ini, manusia dapat lebih mudah memenuhi kebutuhan hidupnya, menggapai cita-cita dan ambisinya maupun merealisasikan sesuatu yang sebelumnya dianggap sebagai sesuatu yang sulit dapat dilaksanakan. Kemudahan yang diperoleh dapat berupa kemudahan dalam bidang kesehatan, pengangkutan pemukiman, pendidikan, kesehatan, komunikasi bahkan sampai alat-alat teknologi canggih seperti persenjataan (Suriasumantri, 2010).

Kemudahan dalam kehidupan manusia akibat perkembangan ilmu pengetahuan dan teknologi telah membangun peradaban baru umat manusia.serta memberikan kemudahan dan kesejahteraan kehidupan manusia. Namun, kemajuan itu tidak selamanya membawa berkah tetapi juga dapat menyebabkan malapetaka dan kesengsaraan, bahkan boleh dianggap sebagai hukuman bagi umat manusia. Sejak awal sejarah perkembangannya, ilmu telah dikaitkan dengan tujuan perang. Fakta ini dapat menimbulkan gejala dehumanisasi bahkan bisa meniadakan hakikat manusia itu sendiri sebagai makhluk sosial. Manusia sebagai mahluk sosial memiliki kewajiban untuk mensejahterakan dirinya, keluarga dan lingkungannya. Tetapi, sifat keserakahan manusia telah membawa pada sifat-sifat untuk menguasai orang lain dan bahkan menguasai dunia untuk kepentingan diri dan tujuan politiknya. Sifat keserakahan ini menyebabkan manusia mencari cara yang paling mudah dengan berbagai jalan seperti menggunakan senjata untuk menjajah hak-hak orang lain atau negara lain.IImu pengetahuan telah menghantarkan manusia pada penguasaan teknologi dan mempermudah kehidupan manusia. Dengan teknologi, manusia dapat membuat senjata yang canggih yang dapat 
memusnahkan umat manusia lain. Salah satu hasil ilmu pengetahuan dan teknologi dalam bidang persenjataan adalah senjata biologi. Senjata berbahaya ini dapat menimbulkan kehancuran dan kerusakan yang teramat dahsyat. Senjata biologis sering disebut sebagai "senjata nuklir orang miskin". Biaya maupun teknologi yang diperlukan untuk membuat senjata biologis jauh lebih rendah dan mudah dibanding senjata nuklir atau kimia. Walaupun demikian, efek penghancuran massanya tidak kalah hebat dibanding kedua senjata tadi. Menurut perhitungan Office of Technology Assessment di Konggres Amerika pada tahun 1993, $100 \mathrm{~kg}$ spora bakteriBacillus anthracis yang disebarkan di atas ibukota Washington bisa menimbulkan korban 3 juta jiwa. Dalam kenyataannya, penyebaran bakteri serupa dari instalasi pembuatan senjata biologis Rusia di kota Yekaterinburg pada tanggal 2-3 April 1979 telah menelan korban tewas 'puluhan ribu jiwa' di daerah sekitarnya menurut laporan Union for Chemical Safety.

Kenyataan ini telah menjadi bagian dalam melahirkan pemikiran tentang hakikat ilmu dalam filsafat. Perkembangan ilmu pengetahuan dan teknologi sudah selayaknya memberikan dampak positif pada kehidupan manusia berupa ilmu pengetahuan dan teknologi yang didampingi oleh nilai-nilai moral. Bahasan tentang moral, etika penggunaanteknologi senjata biologis akan dibahas dalam artikel ini ,dengan tujuan untuk memberikan kesadaran kepada kita tentang bahaya senjata biologis apabila digunakan untuk mencapai ambisi dan cita-cita manusia untuk menguasai manusia lainnya dengan cara yang salah.

Perjanjian di tingkat internasional yang melarang penggunaan senjata biologis dimulai sejak Geneva Protocol tahun 1925. Akan tetapi, sejarah memperlihatkan bahwa pengembangan senjata biologis tetap berlanjut. Salah satu contoh yang terdokumentasi adalah penggunaan senjata biologis oleh tentara Jepang dalam perang dunia ke-2 di Cina. Untuk itu, pada tahun 1972 disepakati perjanjian Biological and Toxin Weapon Convention (BTWC) yang disponsori oleh PBB. Dalam perjanjian ini, lebih ditegaskan lagi mengenai "pelarangan dalam pengembangan, pembuatan dan penyimpanan segala jenis senjata biologis". Sampai saat ini tak kurang dari 140 negara telah menandatangi perjanjian ini, termasuk Indonesia, Amerika, dan Rusia.Akan tetapi kelemahan utama BTWC adalah tidak adanya kesepakatan bersama untuk pengawasan dan pembuktian, sehingga terbukti masih ada negara yang melakukan pelanggaran ,mengembangkan senjata biologis walaupun ikut menandatangani persetujuan tersebut. Penggunaan senjata biologi ini, akan dikaji secara aksiologi akan memberikan pandangan dari aspek moral. Aksiologi dipahami sebagai teori nilai yang berkaitan dengan penggunaan dari pengetahuan yang diperoleh.

\section{Metode}

Kajian ini dilakukan dengan studi literatur dari beberapa sumber yang relevan. Kajiankajian tentang berbagai informasi senjata biologis, baik mengenai jenis,kerugian, bahaya, pengembang dan penggunanya disajikan pada artikel ini , lalu dikaji dengan pandangan secara aksiologi yang ditinjau dari segi moral, segi kemanusiaan.

\section{Hasil dan Pembahasan}

\section{Terminologi Aksiologi}

Aksiologi adalah cabang filsafat yang membicarakan tentang orientasi atau nilai suatu kehidupan. Aksiologi disebut juga teori nilai karena ia dapat menjadi sarana orientasi manusia dalam usaha menjawab suatu pertanyaan yang amat fundamental, yakni bagaimana manusia harus hidup dan bertindak? Yang pada akhirnya teori nilai ini melahirkan etika dan estetika. Secara moral aksiologi dapat dilihat dari adanya peningkatan kualitas kesejahteraan dan kemaslahatan umat pada perkembangan keilmuan. Nilai-nilai bertalian dengan apa yang memuaskan keinginan atau kebutuhan seseorang, kualitas dan harga sesuatu atau appreciative respon( Adib , 2010 ). Kata aksiologi secara bahasa berasal dari kata Yunani, axion; nilai dan logos; ilmu, yang berarti teori tentang nilai (value). Pertanyaan masalah ini menyangkut antara lain : untuk apa pengetahuan ilmu ini digunakan? Bagaimana kaitan antara cara penggunaannya dengan kaidah-kaidah moral? Bagaimana kaitan metode ilmiah yang digunakan dengan norma-norma moral dan profesianal ( Vardiansyah D dalam SanprayogiM, Chaer T, 2017, 2008)

Aksiologi memiliki sebuah makna sebagai value dan valuation. Dalam pengertian sempit, nilai dapat memiliki arti sebagai sesuatu yang baik, menarik, dan bagus. Adapun dalam pengertian luas, nilai memiliki makna sebagai suatu kewajiban, kebenaran, dan kesucian. Nilai sebagai kata benda konkret, contohnya ketika kita berkata kepada sesuatu yang bernilai 
seperti: nilainya, nilai dia, dan sistem nilai. Nilai digunakan sebagai kata kerja dalam ekspresi menilai, memberi nilai, dan dinilai. (Jalaludin dan Idi, 1997:106). Nilai juga lebih menunjukkan kepercayaan tentang baik dan buruk dari seseorang. Dengan demikian nilai bagi seseorang itu merupakan pandangan atau anggapan atau kepercayaan mengenai sesuatu itu baik atau buruk.

Pendapat lain tentang aksiologi telah dikemukakan oleh Suriasumantri (2010) dan Firman (2018) yang menyatakan bahwa aksiologi adalah teori yang berkaitan dengan kegunaan dari pengetahuan yang diperoleh.Aksiologi juga menujukkan kaidah-kaidah apa yang harus kita perhatikan di dalam menerapkan ilmu menjadi hal yang praktis. Aksiologi memuat pemikiran tentang masalah nilai-nilai termasuk nilai-nilai ke-Tuhanan. Misalnya nilai moral, nilai agama, nilai keindahan (estetika). Aksiologi mengandung pengertian lebih luas dari etika atau higher values of life (nilai-nilai kehidupan yang bertaraf tinggi). Aksiologi memberikan jawaban atas beberapa pertanyaan seperti: untuk apa pengetahuan yang berupa ilmu itu dipergunakan? Bagaimana kaitan antara cara penggunaan tersebut dengan kaidah-kaidah moral? Bagaimanakah kaitan antara teknik prosedural yang merupakan operasionalisasi metode ilmiah dengan norma-norma moral atau profesional?"

Hasil kemajuan teknologi dapat membawa sebuah negara ke arah kemajuan dalam berbagai bidang, baik sosial, ekonomi dan persenjataan. Kemajuan tersebut membawa banyak perubahan kebiasaan, tradisi dan budaya. Berdasarkan penelitian yang dilakukan terdapat lima hal yang telah berubah selama periode perkembangan teknologi di dunia diantaranya: (1) perubahan-perubahan dalam struktur industri berupa: meningkatnya sektor jasa dan peranan teknologi canggih pada bidang manufaktur, (2) perubahan-perubahan dalam struktur pasar berupa pasar persenjataan, (3) pengelolaan bisnis menjadi semakin beragam, (4) perubahanperubahan dalam struktur kepegawaian berupa: tenaga professional yang telah terlatih dalam bidang teknik menjadi semakin meningkat, dan (5) perubahan-perubahan struktur masyarakat berupa: meningkatnya jumlah penduduk usia tua dan konsep "keluarga besar" dalam proses diganti dengan konsep "keluarga kecil".

Perubahan-perubahan dalam nilai-nilai sosial berupa penghargaan yang lebih tinggi terhadap keuntungan secara ekonomis daripada masalah-masalah keadilan, meningkatnya kecenderungan masyarakat untuk bersikap individualistik dan semakin merajalelanya peperangan dan persenjataan. Dalam bidang industri persenjataan telah lahir persenjataan canggih yang salah satunya dalam bentuk senjata biologis. Perkembangan senjata ini telah mendominasi salah satu hasil perkembangan dalam bidang ilmu pengetahuan.

\section{Perkembangan Riset dan Aplikasi Senjata Biologis}

Proses riset dimaknai sebagai wadah pergulatan yang dilalui oleh peneliti. Peneliti akan menemukan jawaban atas segala hal yang diajukan dalam rangka menemukan jawaban untuk memenuhi kebutuhan hidup manusia. Dalam proses penelitian inilah sesungguhnya akan terlihat uji coba atas kemampuan dan ketrampilan peneliti untuk mengukur sejauhmana peneliti berkualitas atas riset yang dilakukan. Hasil riset ini berupa temuan dan teknologi tepat guna baik berupa barang, benda dan hasil teknologi canggih seperti peralatan persenjataan perang seperti senjata kimia.

Dalam banyak hal, seringkali dijumpai persiapan-persiapan atau bekal pra riset yang banyak mengalami perubahan sebagai akibat dari situasi dan kondisi lapangan yang memberikan tuntutan lain seperti tujuan politik dan cita-cita pemimpin. Contoh yang seringkali dijumpai adalah terjadinya penemuan-penemuan hasil teknologi yang menimbulkan masalah baru yang menjadi masalah dalam penelitian dan diluar prediksi dalam rancangan penelitian sebelumnya. Hal ini sepenuhnya tergantung pada peneliti untuk melanjutkan atau menata ulang risetnya.

Aksiologi dalam riset bertujuan agar riset yang dilakukan bermanfaat bagi kemaslahatan hidup manusia, baik secara teoritis atau akademik maupun secara empirik. Nilai manfaat dari ilmu pengetahuan sebaiknya terpikirkan sejak peneliti memulai pra riset. Seringkali kemanfaatan riset ini baru terpikirkan dan digarap pada penyusunan akhir-akhir penulisan laporan penelitian. Padahal secara eksplisit maupun implisit, nilai manfaat selalu menyertai setiap langkah raiset. Peneliti memiliki kewajiban moral dalam memikirkan manfaat setiap riset yang akan dilakukannya.

Dalam setiap rancangan penelitian perlu dipikirkan manfaat dan tujuan penelitian. Kewajiban moral dan sosial dapat diaplikasikan melalui tujuan penelitian dan manfaat yang akan menjadi kontribusi terhadap kehidupan manusia. Nama lain yang sering digunakan dalam pengertian nilai manfaat adalah kontribusi penelitian atau kegunaan penelitian. Sebaiknya 
tujuan dan manfaat penelitian ini mengandung dua aspek manfaat yaitu aspek-aspek teoritis dan praktis. Manfaat ini akan terjelma dalam hasil riset baik itu penelitian literatur maupun penelitian lapangan.

\section{Bahaya Senjata Biologi Bagi Umat Manusia}

Senjata biologis yaitu senjata yang mengandung bahan-bahan biologi atau mikroba seperti virus, bakteri, jamur atau toksin dari makhluk hidup yang dapat menimbulkan penyakit atau kematian pada manusia atau ternak. Beberapa jenis mikroba yang dapat digunakan sebagai senjata biologis antara lain, Bacillus anthracis, Yersinia pestis, Clostridium botulinum, Mycobacterium tuberculosis, virus variola, virus ebola, virus polio dll. Mikroba-mikroba ini dapat masuk dan keluar tubuh manusia melalui berbagai organ tubuh, saluran pernapasan, saluran pencernaan, saluran kemih, kulit atau melalui organ lainnya. Infeksi mikroba-mikroba ini akan menimbulkan gejala-gejala klinik yang spesifik untuk setiap mikroba ( Jawetz,1996 ; Joklik,1992).

Menurut perhitungan Office of Technology Assessment di Kongres Amerika pada tahun 1993, $100 \mathrm{~kg}$ spora bakteri Bacillus anthracis yang disebarkan di atas ibukota Washington, bisa menimbulkan korban 3 juta jiwa. Dalam kenyataannya, penyebaran bakteri serupa dari instalasi pembuatan senjata biologis Rusia di kota Yekaterinburg pada tanggal 2-3 April 1979 telah menelan korban tewas 'puluhan ribu jiwa' di daerah sekitarnya menurut laporan Union for Chemical Safety. Berbeda dengan senjata nuklir, senjata biologis punya banyak jenis.. Senjata biologis menggunakan agen hayati seperti virus dan bakteri, jumlahnya cenderung bertambah dengan munculnya berbagai macam penyakit infeksi fatal baru seperti virus Ebola, virus Lassa dan lain-lain. Namun demikian, agen yang benar telah dipakai sebagai senjata biologis adalah bakteri yang telah lama dikenal manusia, mudah didapatkan di alam dan tidak sulit penanganannya. Bacillus anthracis, penyebab penyakit anthrax adalah pilihan utama dan telah terbukti dipakai dalam kejadian di Amerika dandicoba dibuat di Rusia serta Irak. Selain itu, bakteri yang mematikan dan tercatat sebagai agen senjata biologis adalah Yersinia pestis penyebab penyakit pes, Clostridium botulinium yang racunnya menyebabkan penyakit botulism, Francisella tularensis (tularaemia) dan lain-lain (Jawetz, 1996,Joklik 1992). Di lain pihak, karena bakteri-bakteri patogen itu sudah dikenal lama, pengobatannya sudah diketahui dengan berbagai antibiotika dan pencegahannya dapat dilakukan dengan vaksinasi.

Ada yang lebih mengerikan adalah senjata biologis dengan agen yang telah direkayasa secara bioteknologi sehingga tahan antibiotika, lebih mematikan, stabil dalam penyimpanan dan sebagainya. Rekayasa genetika yang paling mudah adalah rekayasa untuk sifat resistensi terhadap antibiotika. Sifat seperti ini biasanya hanya ditimbulkan oleh kumpulan gen sederhana atau bahkan gen tunggal, sehingga mudah dipindahkan dari satu jenis bakteri ke bakteri lain. Teknologi ini juga telah menjadi standar dalam setiap eksperimen biologi molekuler. Bacillus anthracis yang dapat dimatikan dengan antibiotika jenis Penicillin dengan mudah dapat dibuat resisten dengan mentransfer gen enzim $\beta$-lactamase ( Jawetz, 1996). Biopreparat, jaringan instalasi pembuatan senjata biologis di Rusia, dikabarkan telah merekayasa bakteri penyebab pes dengan resistensi terhadap 16 jenis antibiotika. Metode rekayasa lain yang memungkinkan adalah dengan teknologi yang disebut "evolusi yang diarahkan" (directed evolution). Metode ini dikembangkan pertama kali tahun 1994 oleh Dr. Willem Stemmer peneliti di perusahaan bioteknologi, Maxygen yang berbasis di kota Redwood, California. Metoda yang berdasarkan pada pertukaran fragmen DNA secara acak, atau disebut dengan istilah DNA shuffling, ini pertama kali diterapkan pada gen tunggal yang mengkode sebuah protein. Namun kemudian dikembangkan untuk level yang lebih besar, yaitu kumpulan gen sampai genom. Stemmert telah berhasil merekayasa bakteri Escherichia coli yang memiliki resistensi terhadap antibiotika Cefotaxime, 32 ribu kali lebih tinggi. Hasil penelitian tim peneliti dari CSIRO-Australia yang dipimpin oleh Dr. Ronald J. Jackson yang dipublikasikan di Journal of Virology edisi Februari 2001, memberikan gambaran yang jelas. Tim peneliti itu melakukan rekayasa genetika terhadap virus mousepox untuk mengkontrol fertilitas tikus. Virus ini tidaklah begitu berbahaya, namun ketika keduanya disisipi gen protein interleukin-4, mousepox tersebut menjadi sangat mematikan. Padahal tujuannya hanyalah untuk meningkatkan efisiensi virus menurunkan kesuburan tikus dengan memperbanyak produksi antibodi terhadap sel telurnya sendiri. Hasil yang diluar dugaan ini menggemparkan masyarakat ilmiah karena virus mousepox merupakan kerabat dekat virus smallpox penyebab penyakit cacar. Dapat dibayangkan teknologi ini sangat mungkin diterapkan kepada virus cacar yang menduduki peringkat pertama dalam tingkat kebahayaannya sebagai senjata biologis. 


\section{Pandangan Aksiologi Terhadap Risetdan Penggunaan Senjata Biologis}

Kehidupan manusia yang tidak dapat dilepaskan dari agama telah memberikan batasan tentang tata nilai dan moral yang sekaligus membatasi penggunaan ilmu dan teknologi untuk selalu taat akan nilai-nilai dan moral. Pada sebagian orang, para pengikut faham ilmu yang bebas nilai telah berjuang agar ilmu memperoleh otonomi dalam melakukan penelitian dalam rangka mempelajari alam sebagai mana adanya .Konflik antara yang menghendaki ilmu selalu mempertimbangkan nilai moral dan imu yang bebas nilai telah berkembang ratusan tahun (Suriasumantri, 2010).

Dalam filsafat, penerapan ilmu berupa teknologi berkaitan erat dengan aksiologi keilmuan. Aksiologi keilmuan ini diartikan sebagai sesuatu yang berkaitan dengan kegunaan ilmu pengetahuan yang diperoleh ( Firman, 2018).. Sebagai contoh, penggunaan teknologi berupa senjata biologis telah menyebabkan kehancuran dan penderitaan umat manusia.Berbeda dengan Senjata kimia, senjata biologis merupakan senjata yang menggunakan patogen sebagai alat untuk melukai, melumpuhkan dan membunuh. Patogen bisa meliputi bakteri, virus, maupun organisme penghasil penyakit. Terkadang senjata yang memiliki unsur toksin berbahaya juga disebut Senjata Biologi. Senjata jenis ini bukanlah senjata baru, karena pada masa lampau bangsa Romawi sudah memanfaatkan pedang yang dicelupkan ke pupuk dan sisa hewan yang membusuk sebelum berperang.Pada tahun 1754 1760 terjadi peperangan antara bangsa Britania Utara dan bangsa Indian yang melibatkan penggunaan virus cacar.

Ketika itu, Britania Utara memberikan pakaian dan selimut dari rumah sakit yang merawat penderita cacar kepada bangsa Indian untuk memusnahkan bangsa tersebut. Pada Perang Dunia I, Jerman menggunakan dua bakteri patogen, yaitu Burkholderia mallei penyebab Glanders dan Bacillus anthracis penyebab Antrax untuk menginfeksi ternak dan Kuda Tentara Sekutu. Pada tahun 1932-1935, Jepang mengembangkan program pembuatan senjata biologi di Cina yang dinamakan Unit 731. Sebanyak 3.000 ilmuwan Jepang bekerja untuk melakukan penelitian terhadap berbagai agen biologi yang berpotensi sebagai senjata, misalnya kolera, pes, dan penyakit seksual yang menular. Eksperimen yang dilakukan menggunakan tahanan Cina yang mengakibatkan \pm 10.000 tahanan mati pada masa itu. Sejak saat itu, tidak hanya Jepang yang mengembangkan senjata biologi, namun juga diikuti oleh negara-negara lain seperi Amerika Serikat dan Uni Soviet.

Penggunaan senjata biologis ini telah melampaui nilai-nilai moral dan hak asasi manusia. Hasil pengembangan ilmu pengetahuan ini telah digunakan sebagai penghancur umat manusia itu sendiri. Padahal hakikat pengembangan ilmu pengetahuan itu bertujuan untuk membantu mencapai kesejahteraan umat manusia.

\section{Penggunaan Senjata Biologis dipandang dari Segi Moral dan Kemanusiaan Segi Moral}

Secara tidak langsung penggunaan senjata biologis dapat merusak moral sebuah bangsa. Bagi bangsa yang terkena senjata biologis biasanya diintai oleh keterpurukan dan guncangan mental, hal ini dialami oleh penduduk yang menjadi sasaran senjata biologis. Biasanya, senjata biologis digunakan untuk penyerangan terhadap tentara musuh di medan perang ataupun faksi-faksi militer negara yang bersitegang, namun tak jarang masih ada negara yang mengarahkan senjata biologis mereka pada penduduk dari negara yang bersitegang. Dilihat dari sisi ini jelas bahwa penggunaan senjata biologis harusnya tak perlu digunakan selain dari tujuan utamanya untuk menjatuhkan musuh.Senjata biologis dapat menyebabkan keruntuhan moral bagi sasarannya,dalam penyebaran yang terus berkembang dari waktu ke waktu senjata biologis dikategorikan sebagai salah satu senjata yang sangat mematikan dan dilarang penyebarannya.

Senjata biologis yang dikembangkan di Irak adalah senjata biologis yang di duga dapat menyerang korbannya langsung pada sistem syaraf motorik.Korban yang terserang meskipun selamat kemungkinan akan mengalami cacat mental. Senjata biologis yang sedang dalam tahap pengembangan ini memperlihatkan bahwa penggunaan senjata biologis tidak tepat mengingat perkembangan zaman yang merujuk pada globalisasi, keamanan dan kerja sama antar negara dalam pencegahan terjadi kembali perang dunia. Selain itu organisasi-organisasi yang ada di dunia saat ini seperti PBB mengangggap penyebaran senjata biologis merupakan sebuah ancaman besar bagi perkembangan dan pertahanan moral sebuah bangsa, sehingga jika dilihat dari segi moral jelas penggunaan senjata biologis adalah sesuatu tindakan yang dikecam dan tidak baik. Jika penggunaannya masih terus berlanjut, hal ini menunjukkan betapa minimnya keperdulian dunia terhadap moral sebuah bangsa. 


\section{Segi Kemanusiaan}

Penggunaan senjata biologis dilihat dari segi kemanusiaan merupakan sesuatu yang kurang manusiawi dan dianggap lebih menyakitkan, bila dibandingkan dengan senjata nuklir ataupun yang lainnya karena dalam penggunaannya senjata biologis tidak langsung membuat korban atau sasaranya mati, namun korban harus terlebih dulu merasakan penderitaan dari rasa sakit yang di alami efek penyebaran bakteri atau virus yang membutuhkan waktu cukup lama sampai pada tahap kematian. Namun tak semua senjata biologis yang digunakan berujung pada kematian, sebagian senjata biologis menggunakan bakteri yang tidak mematikan namun tetap berbahaya karena jika tidak ditangani dengan baik tetap saja bisa berujung pada kematian.Jumlah bakteri atau virus yang digunakan cenderung bertambah dengan munculnya berbagai macam penyakit infeksi fatal baru seperti virus Ebola, Suatu jenis bakteri yaitu Bacillus anthracis, penyebab penyakit anthrax adalah pilihan utama dan telah terbukti dipakai dalam kejadian di Amerika maupun, Rusia serta Irak. Dengan perkembangan yang sulit dihentikan, melalui metode rekayasa genetika semakin banyak jenis bakteri ataupun virus yang digunakan sebagai senjata biologis yang dapat mematikan atau sulit diobati.

\section{Kesimpulan}

Perkembangan ilmu selayaknya dapat menghasilkan teknologi yang dapat memberikan manfaat bagi kehidupan manusia, mempermudah dan membantu tercapainya cita-cita umat manusia. Namun, keserakahan umat manusia telah melahirkan teknologi canggih berupa senjata biologis sebagai pemusnah masal, yang memberikan dampak negatif pada umat manusia. Teknologi canggih berupa senjata biologi telah menjadi senjata pemusnah yang dapat membunuh umat manusia dalam peperangan. Senjata biologi juga telah banyak digunakan untuk mencapai cita-cita politik segelintir orang. Sebaiknya pengembangan ilmu pengetahuan yang menghasilkan teknologi harus dilandasi nilai-nilai agama, moral dan estetika.

\section{Daftar Pustaka}

nn.....,2001, Bahaya Senjata Biologis, Journal of Virology, ed Februari

Adib A , 2010, Filsafat Ilmu, Yogyakarta: Pustaka Pelajar

Firman H, 2018, Modul Perkuliahan Filsafat Sains, Sekolah Pascasarjana, Universitas Pendidikan Indonesia

Jawetz, Melnick,Adelberg, 1996, Mikrobiologi Kedokteran, Edisi ke-20, Jakarta, EGC

Joklik, Willet, Amos, 1992, Zinnser Microbiology, $20^{\text {th }}$ Edition, USA, Appleton \& Lange

Jalaluddin ,Abdullah Idi. 1997. Filsafat Pendidikan. Jakarta: Gaya Media Pratama.

Suriasumantri, Jujun S. 2010. Filsafat IImu: Sebuah Pengantar Populer. Jakarta: PT Penebar Swadaya.

Susanto, A. 2011. Filsafat IImu: Suatu Kajian dalam Dimensi Ontologis, Epistemologis dan Aksiologis. Jakarta: PT Bumi Aksara

Sanprayogi M, Chaer T, 2017 ,Aksiologi Filsafat Ilmu dalam Pengembangan keilmuan, Al Murabbi Volume 4, Nomor 1, Juli 2017 ISSN 2406-775X 